\title{
PENGARUH DISIPLIN KERJA, PENGAWASAN, DAN KOMPENSASI TERHADAP KINERJA PEGAWAI PELINDO IV PANTOLOAN
}

\author{
HARTINA \\ NILUH PUTU EVVY ROSSANTY \\ MOH. ALI MURAD
}

Program Studi Manajemen, Fakultas Ekonomi\& Bisnis, Universitas Tadulako Email: hartinahasyim99@gmail.com;

\section{ABSTRACT}

The purpose of this study is to determine and analyze the influence of work discipline, supervision, and compensation variables to theemployees performance of Pelindo IV Branch of Pantoloan. The sample used in this study were 46 respondents, with the sampling technique used is the saturated or census sampling method. The method of data analysis used in this study was Multiple Linear Regression. The result shows that work discipline, supervision, and compensation simultaneously had a significant influenceto the employees performance of Pelindo IV Branch of Pantoloan. Partially Work discipline has a significant influenceto the employees performance of Pelindo IV Branch of Pantoloan. Partially supervision has a significant influenceto the employees performance Pelindo IV Branch of Pantoloan. Partially compensation has a significant influenceto the employees performance of Pelindo IV Branch of Pantoloan.

Keywords: Work discipline, Supervision, Compensation, Employee Performance.

\section{ABSTRAK}

Tujuan dari penelitian ini yaitu untuk mengetahui dan menganalisis pengaruh variabel disiplin kerja, pengawasan, dan kompensasi terhadap kinerja pegawai Pelindo IV Pantoloan.Sampel yang digunakan penelitian ini yaitu sebanyak 46 responden, dengan teknik penarikan sampel yang digunakan adalah metode sampling jenuh atau sensus.Metode analisis data yang digunakan dalam penelitian ini adalah Regresi Linear Berganda. Hasil penelitian menunjukkan bahwa disiplin kerja, pengawasan, dan kompensasi secara serempak berpengaruh signifikan terhadap kinerja pegawai Pelindo IV Pantoloan Disiplin kerja secara parsial berpengaruh signifikan terhadap kinerja pegawai Pelindo IV Pantoloan.Pengawasan secara parsial berpengaruh signifikan terhadap kinerja pegawai Pelindo IV Pantoloan.Kompensasi secara parsial berpengaruh signifikan terhadap kinerja pegawai Pelindo IV Pantoloan.

Kata Kunci: Disiplin kerja, Pengawasan, Kompensasi, Kinerja Pegawai

\section{PENDAHULUAN}

Persaingan global saat ini, dunia kerja sangat membutuhkan orang yang bisa berfikir untuk maju, cerdas, inovatif dan mampu berkarya dengan semangat tinggi.Peran dari sumber daya manusia sendir yang mempunyai peran penting dalam suatu organisasi atau perusahaan, juga diprioritaskan pada aspek manajerial yang matang dalam pengelolaan organisasi.Berbagai organisasi atau perusahaan berusaha meningkatkan kinerja dari seluruh elemen yang ada dalam organisasi masing-masing dengan tujuan mencapai kelangsungan hidup perusahaan.

Persaingan di berbagai sektor membuat proses pengelolaan, pemeliharaan manajemen organisasi semakin mendapatkan perhatian yang serius dari seluruh elemen yang ada dalam perusahaan untuk menciptakan sebuah sistem manajerial yang tangguh dan mampu mengikuti perkembangan. Sumber daya manusia yang dalam hal ini adalah para pegawai dalam organisasi, tentunya berusaha bekerja dengan kemampuan yang mereka miliki agar dapat mencapai kinerja yang tinggi. Konteks inilah, yang membuat seorang pegawai perlu memiliki tingkat disiplin yang baik sehingga ia tetap mampu menjaga 
dan mempertahankan kinerjanya. Sutrisno (2009:135) berpendapat bahwa disiplin kerja pada pegawai sangat dibutuhkan. Disiplin kerja yang baik sangat memungkinkan tujuan organisasi dapat tercapa secara maksimal, serta akan menjamin terpeliharanya tata tertib dan kelancaran pelaksanaan tugas. Demikian pula bagi pegawai akan menambah suasana kerja yang teratur dan menyenankan, serta menambah semangat kerja pegawai.

Selain disiplin kerja yang dapat mempengaruhi kinerja pegawai, yaitu pengawasan pimpinan.Pengawasan oleh pimpinan dapat mengetahui kegiatan-kegiatan nyata dari setiap aspek dan setiap permasalahan pelaksanaan tugas dalam lingkungan satuan organisasi dan bilamana terjadi penyimpangan, maka dengan segera dapat mengambil langkah perbaikan atau tindakan seperlunya sesuai dengan rencana yang telah ditetapkan sebelumnya serta peraturan perundang-undangan yang berlaku.

Organisasi yang baik memiliki struktur organisasi dan tugas yang jelas, sehingga fungsi pengawasan yang menjadi tugas para pimpinan dapat dengan mudah dilaksanakan.Terjadinya penyimpangan mengakibatkan hasil kerja menurun karena itu setiap kegiatan yang sedang berlangsung dalam organisasi haruslah berdasarkan fungsi-fungsi manajemen, dimana salah satu diantaranya adalah fungsi pengawasan.

Perusahaan dalam meningkatkan kinerja pegawai selain disiplin kerja dan pengawasan, kompensasi juga mimiliki peranan penting. Kompensasi mempunyai pengaruh dalam meningkatkan kinerja pegawai, dengan cara pemberian kompensasi yang adil oleh perusahaan (Dessler, 2011:126). Apabila kompensasi dikelola dengan benar maka akan membantu organisasi mencapai tujuannya dan memperoleh, memelihara dan mempertahankan tenaga kerja yang produktif. Kompensasi adalah salah satu bentuk perhatian yang dapat diberikan organisasi kepada pegawai dalam miningkatkan kinerjanya setiap pegawai yang ada pada organisasi.

Pemberian kompensasi tidak semata memberikan imbalan (reward) atas keberhasilan suatu pekerjaan yang telah tercapai, tetapi juga untuk meningkatkan proses kerja, kompetensi sebagai upaya untuk memberikan penghargaan atas usaha pekerjaan yang telah dilakukan seseorang. Dengan memberikan kompensasi, maka diharapkan kinerja pegawai akan meningkat. Kompensasi adalah sesuatu yang diterima para karyawan sebagai balas jasa untuk kerja mereka (Handoko, 2012:155).Kompensasi penting bagi pegawai, sebagai individu karena besarnya kompensasi mencerminkan nilai karya mereka di antara para pegawai lainnya dalam perusahaan.

Pelabuhan Pantoloan merupakan pelabuhan utama yang berada di Kota Palu Propinsi Sulawesi Tengah. Pelabuhan Pantoloan didirikan pada Tahun 1975 yang kemudian pada Tahun 1978 pembangunan pelabuhan Pantoloan tersebut selesai dilaksanakan. Pelabuhan Pantoloan merupakan pelabuhan terbuka yang bertugas memberikan pelayanan dalam negeri. Menjalankan segala aktivitasnya, Pelabuhan Pantoloan telah dijalankan oleh seorang pimpinan yang membawahi pegawai sebagai pelaksana kegiatan operasional.

Hasil observasi dan wawancara awal yang dilakukan pada Bapak Kudrat selaku bagian kepegawaian, diketahui bahwa tingkat disiplin pegawai Pelabuhan Pantoloan Kota Palu masih belum optimal. Hal ini ditandai dengan adanya pegawai yang sering terlambat masuk kerja, pulang sebelum waktunya, meninggalkan kantor pada saat jam kerja. Berdasarkan informasi yang ada, juga mengungkapkan bahwa masih ada pegawai yang tidak mematuhi peraturan, tidak masuk kerja tanpa izin yang sah, serta sakit tanpa pemberitahuan atau surat keterangan dokter. Padahal telah ada kesempatan untuk setiap pegawai diberikan cuti oleh Pelabuhan Pantoloan selama setahun kerja.

Berdasarkan observasi dan wawancara penulis lakukan tentang pengawasan diungkapkan, bahwa pengawasan secara langsung yang dilakukan oleh pimpinan terhadap pegawai masih belum optimal. Hal ini disebabkan pimpinan biasanya tidak berada ditempat. Sehingga berdampak pada kinerja setiap 
pegawai Pelindo IV Pantoloan, yaitu target kerja yang telah ditetapkan tidak dapat tercapai secara maksimal atau sesuai dengan apa yang ditentukan oleh Pelindo IV Pantoloan.

Hasil observasi dan wawancara lebih lanjut yang dilakukan kepada Bapak Kudrat, mengatakan bahwa kompensasi yang diberikan baik langsung maupun tidak langsung sudah cukup baik, namun masih belum sesuai dengan apa yang diharapkan, seperti pemberian insentif/bonus yang diberikan belum sesuai harapan. Dikarenakan pemberian kompensasi hanya dilakukan pada pagawai dalam rangka pencapaian target kerja atau pegawai yang memiliki kontribusi maksimal atas hasil capaian kinerja individu setiap sebulan. Selain itu pembayaran kompensasi juga biasanya terlambat dilakukan, padahal pembayaran tersebut harus dilakukan setiap tanggal 15 bulan berikutnya sesuai peraturan waktu pembayaran tunjangan bulanan pegawai.

\section{KAJIAN LITERATUR DAN PENGEMBANGAN HIPOTESIS}

Disiplin merupakan sikap, tingkah laku dan perbuatan yang sesuai dengan peraturan perusahaan baik yang tertulis maupun yang tidak tertulis.Peraturan yang dimaksud termasuk absensi, lambat masuk, serta cepat pulang karyawan. Sutrisno (2009:92-94) berpendapat bahwa disiplin kerja terdiri tiga komponen, yaitu: 1) Disiplin waktu berarti bersikap faktual terhadap waktu yang ditetapkan termasuk jam mulai kerja, jam istirahat, jam pulang kantor dan jam mulai serta penutupan rapatseminar dan lain-lain. 2) Disiplin moral adalah disiplin yang keluar dari hati nurani untuk berusaha menepati atau menyelesaikan suatu pekerjaan. 3) Disiplin administratif adalah disiplin untuk mengerjakan (atau tidak mengerjakan) seperti yang tertera dalam aturan atau kaidah yang ditetapkan sebelumnya. Kaidah tersebut dapat bersifat tertulis, tidak tertulis, dapat berupa suatu norma hukum, norma kesusilaan, peraturan kepegawaian dan lain-lain.

Pengawasan sebagai salah satu fungsi manajemen dalam pencapaian tujuan yang memegang peranan sangat penting. Tujuan utama dari pengawasan ialah mengusahakan agar apa yang direncanakan menjadi kenyataan. Menurut Winardi (2011:589) dalam pengawasan terdapat beberapa faktor-faktor yang dapat mempengaruhi, yaitu 1) Pengawasan pendahuluan (preliminary control), yaitu prosedur-prosedur pengawasan pendahuluan mencakup semua upaya manajerial guna memperbesar kemungkinan bahwa hasil-hasil aktual akan berdekatan hasilnya dibandingkan dengan hasil-hasil yang direncanakan. 2) Pengawasan pada saat kerja berlangsung (cocurrent control), yaitu concurrent control terutama terdiri dari tindakan-tindakan para suvervisor yang mengarahkan pekerjaan pada bawahan mereka. 3) Pengawasan umpan balik (feed back control), yaitu sifat khas dari metode-metode pengawasan feed back (umpan balik) adalah bahwa dipusatkan perhatian pada hasilhasil historikal, sebagai landasan untuk mengoreksi tindakan-tindakan masa mendatang.

Kompensasi merupakan sesuatu yang diterima karyawan sebagai pengganti kontribusi jasa mereka pada perusahaan.Handoko (2012:155) mengartikan bahwa kompensasi adalah segala sesuatu yang diterima para karyawan sebagai balas jasa untuk kerja mereka. Sastrohadiwiryo (dalam Priansa, 2016:319) menyatakan bahwa kompensasi terdiri atas kompensasi finansial langsung dan tidak langsung, yaitu 1) Kompensasi finansial langsung, yaitu terdiri atas bayaran (pay) yang diperoleh seseorang dalam bentuk gaji, upah, bonus, atau komisi. 2) Kompensasi finansial tidak langsung, merupakan tunjangan, meliputi semua imbalan finasial yang tidak mencakup dalam kompensas finansial langsung seperti program tenaga kerja (jamsostek), pertolongan sosial, pembayaran biaya sakit (berobat), cuti dan lain-lain.

Kinerja karyawan berkaitan dengan mempunyai rasa tanggung jawab yang tinggi dalam mencapai visi dan misi perusahaan, ketepatan dan ketaatan waktu dalam menyelesaikan setiap pekerjaan, memiliki sifat kejujuran yang tinggi dalam bekerja.Byars dan Rue (2008:216) mengemukakan bahwa 
kinerja merupakan hasil keterkaitan antara usaha, kemampuan, dan presepsi tugas.Berikut penjelasan dari ketika dimensi tersebut, yaitu 1) Usaha merupakan hasil motivasi yang menunjukkan jumlah energi (fisik dan atau mental) yang digunakan oleh individu dalam menjalankan tugas. 2) Kemampuan merupakan karakteristik individu yang digunakan dalam menjalankan suatu pekerjaan. Kemampuan ini biasanya tidak dapat dipengaruhi secara langsung dalam jangka pendek. 3) Persepsi tugas merupakan petunjuk dimana individu percaya bahwa mereka dapat mewujudkan usaha-usaha mereka dalam pekerjaannya.

Hipotesis penelitian ini dikemukakan berdasarkan dari rumusan masalah dan kerangka pikir Adapun hipotesis penelitian ini sebagai berikut: $\left(\mathrm{H}_{1}\right)$ Disiplin kerja, pengawasan, dan kompensas secara serempak berpengaruh signifikan terhadap kinerja pegawai Pelindo IV Pantoloan. $\left(\mathrm{H}_{2}\right)$ Disiplin kerja berpengaruh signifikan terhadap kinerja pegawai Pelindo IV Pantoloan. $\left(\mathrm{H}_{3}\right)$ Pengawasan berpengaruh signifikan terhadap kinerja pegawai Pelindo IV Pantoloan. $\left(\mathrm{H}_{4}\right)$ Kompensasi berpengaruh signifikan terhadap kinerja pegawai Pelindo IV Pantoloan.

\section{METODE PENELITIAN}

\section{Jenis Penelitian dan Sumber Data}

Jenis penelitian yang digunakan yaitu bersifat deskriptif kausal.Menurut Gay dalam (Umar, 2005:21) bahwa metode riset deskriptif bertujuan untuk menjawab pertanyaan menyangkut sesuatu pada waktu berlangsungnya riset.Penelitian kausal adalah penelitian untuk menguji hubungan kausalitas antara variabel yang dihipotesakan.Hipotesis ini sendiri menggambarkan hubungan antara dua atau lebih variabel untuk mengetahui apakah suatu variabel berasosiasi atau tidak dengan variabel lainnya.

Sumber data dalam penelitian terdiri dari Data Primer dan Data Sekunder.Data Primer merupakan data yang diperoleh secara langsung dari subyek penelitian melalui observasi dan wawancara serta kuesioner yang disebarkan kepada responden. Data Sekunder merupakan data yang diperoleh secara tidak langsung dari obyek penelitian berupa dokumen atau laporan-laporan, berupa gambaran umum lokasi penelitian, serta data lainnya yang relevan dengan penelitian ini.

\section{Populasi dan Sampel}

Populasi diartikan sebagai jumlah keseluruhan anggota yang diteliti (Istijanto, 2005:109).Mengingat penelitian ini dilakukan pada BUMN dengan subyek penelitian adalah pegawai Pelindo IV Cabang Pantoloan, dalam penelitian ini populasi diketahui sebanyak 46 orang.

Sampel merupakan bagian yang diambil dari populasi (Istijanto, 2005:109).Mengingat dalam penelitian ini unsur populasi terbatas, maka seluruh unsur populasi tersebut dijadikan sampel yang berjumlah 46 orang.Adapun dasar penentuan sampel tersebut, yaitu menggunakan teknik penraikan sampel metode sampling jenuh atau yang biasa dikenal sensus.

\section{Pengujian Instrumen Penelitian}

Azwar (dalam Hartono, 2013:146) mengartikan validitas yaitu sejauh mana ketepatan dan kecermatan suatu alat ukur dalam melakukan fungsi ukurnya.untuk mengetahui apakah instrumen tersebut valid, digunakan analisis kesahihan butir dengan melihat nilai Corrected Item Total Correlation (Korelasi Total). Solimun (2005:70) mengatakan bilamana koefisien korelasi antar skor suatu indikator dengan skor total seluruh indikator adalah positif dan lebih besar 0,3 $(\mathrm{r}>0,3)$ maka instrumen tersebut dianggap valid. Berikut hasil perhitungan uji validitas yang telah dilakukan dengan melihat corrected item-total correlation melalui hasil pengujian SPSS 16 for windows. 
Berdasarkan hasil pengujian diperoleh hasil setiap item pernyataan yang digunakan dalam mengukur variabel kinerja pegawai memiliki nilai Corrected Item Total Correlation lebih besar dari nilai r-kritis, sehingga dapat disimpulkan seluruh item pernyataan dapat dinyatakan valid dan layak digunakan pada pengujian selanjutnya.

\section{Uji Reabilitas}

Sekaran (dalam Hartono, 2013:146) mengartikan bahwa reliabilitas adalah suatu pengukur menunjukkan stabilitas dan konsistensi dari suatu intrumen yang mengukur suatu konsep dan berguna untuk mengakses "kebaikan" dari suatu pengukur. Menurut Solimun (2005:71) berpendapat bahwa suatu instrumen dapat dikatakan reliabel manakalah memenuhi standar koefisien alpha Cronbach lebih besar dari $0.6(\alpha>0.6)$.

Berdasarkan hasil pengujian diketahui bahwa semua variabel mempunyai Alpha $(\alpha)>0,60$ Sehingga dapat dikatakan semua konsep pengukur masing-masing variabel dari kuesioner adalah reliabel yang berarti bahwa kuesioner yang digunakan dalam penelitian ini merupakan kuesioner yang handal.

\section{Uji Asumsi Klasik}

Penggunaan model analisis regresi berganda terikat dengan sejumlah asumsi dan harus memenuhi asumsi-asumsi klasik yang mendasari model tersebut. Pengujian asumsi yang harus dipenuhi syaratsyarat agar persamaan regresi dapat digunakan dengan baik (uji persyaratan analisis). Berikut adalah beberapa pengujian asumsi klasik dalam penelitian ini:

1. Uji normalitas, uji normalitas digunakan untuk menguji apakah dalam sebuah model regresi variabel (pengganggu) dependen dan independen atau keduanya memiliki distribusi norma (Ghozali, 2013:160)

2. Uji Multikolinieritas, uji multikolinieritas digunakan untuk menguji apakah model regresi ditemukan adanya kolerasi antara variabel bebas independen (Ghozali, 2013:105).

3. Uji Heteroskedastisitas, uji heteroskedastisitas menurut Ghozali (2013:139) uji heteroskedastisitas yaitu untuk menguji apakah dalam model regresi terjadi ketidaksamaan variance dari residual satu pengamatan ke pengamatan yang lain.

Analisis data statistiknya menggunakan analisis regresi, Teknik analisis regresi yang digunakan adalah analisis regresi berganda. Analisis ini digunakan untuk mengetahui ada tidaknya pengaruh antara variabel independen $(\mathrm{X})$ terhadap variabel dependen $(\mathrm{Y})$, yakni pengaruh Disiplin Kerja $\left(\mathrm{X}_{1}\right)$ Pengawasan $\left(\mathrm{X}_{2}\right)$ dan Kompensasi $\left(\mathrm{X}_{3}\right)$ terhadap Kinerja Pegawai $(\mathrm{Y})$. Selain itu, analisis regresi sangat baik digunakan untuk mengetahui kecenderungan perubahan satu variabel yang dapat mempengaruhi variabel lainnya. Berikut adalah persamaan regresi berganda:

$$
\mathbf{Y}=\mathbf{a}+\mathbf{b}_{1} \mathbf{X}_{1}+\mathbf{b}_{2} \mathbf{X}_{2}+\mathbf{b}_{3} \mathbf{X}_{3}+\mathbf{e}
$$

Dimana :

$\mathrm{Y}=$ Kinerja Pegawai

$\mathrm{X}_{1}=$ Disiplin Kerja

$\mathrm{X}_{2}=$ Pengawasan

$\mathrm{X}_{3}=$ Kompensasi

$\mathrm{A}=$ Konstanta / intercept

$\mathrm{b}_{1}-\mathrm{b}_{4} \quad=$ Koefisien regresi

e $=$ Kesalahan Penganggun (error).

\section{HASIL DAN PEMBAHASAN}

Hasil Analisis Regresi Linear Berganda

Rekapitulasi Hasil Analisis Regresi Linear Berganda 


\begin{tabular}{|l|l|l|l|l|}
\hline \multicolumn{5}{|c|}{ Dependen Variabel Y = Kinerja Pegawai } \\
\hline Variabel Independen & B & Beta & t $_{\text {hitung }}$ & Sig.t \\
\hline (Constant) & .686 & & 1.350 & .184 \\
\hline X1_Disiplin_Kerja & .234 & .254 & 2.389 & .021 \\
\hline X2_Pengawasan & .399 & .442 & 3.391 & .002 \\
\hline X3_Kompensasi & .216 & .272 & 2.137 & .038 \\
\hline $\begin{array}{l}\text { Multiple R R }=0.751 \\
\text { R Square }=0.565\end{array}$ & \multicolumn{5}{|c|}{$=0.000$} \\
\hline
\end{tabular}

Sumber: Output SPSS 16 for Windows, Data diolah, 2019

Berdasarkan Tabel rekapitulasi regresi linear berganda di atas, maka dapat dimasukan persamaan regresi linear berganda melalui nilai koefisien regresi (B). Lebih jelasnya bentuk persamaan tersebut dapat dilihat sebagai berikut:

$$
Y=0.686+0.234 X_{1}+0.399 X_{2}+0.216 X_{3}
$$

Bentuk persamaan tersebut, juga menunjukan bahwa variabel independen yang dianalisis yaitu variabel disiplin kerja (X1), pengawasan (X2) dan kompensasi (X3) memberi pengaruh positif terhadap variabel dependen (Y), yaitu kinerja pegawai Pelindo IV Cabang Pantoloan. Untuk lebih jelanya hasil bentuk persamaan tersebut, akan di uraikan sebagai berikut:

1. Nilai konstanta pada persamaan regresi menunjukkan bahwa sebelum adanya variabel independen yang terdiri dari disiplin kerja, pengawasan, dan kompensasi, maka kinerja pegawai Pelindo IV Cabang Pantoloan sebesar 0.686.

2. Setiap terjadi peningkatan dalam disiplin kerja, akan berpengaruh pada peningkatan kinerja pegawai Pelindo IV Cabang Pantoloan sebesar 0.234 atau 23.4\%.

3. Setiap terjadi peningkatan dalam pengawasan, akan berpengaruh pada peningkatan kinerja pegawai Pelindo IV Cabang Pantoloan sebesar 0.399 atau 39.9\%.

4. Setiap terjadi peningkatan dalam kompensasi, akan berpengaruh pada peningkatan kinerja pegawai Pelindo IV Cabang Pantoloan sebesar 0.216 atau 21.6\%.

\section{Hasil Pengujian Hipotesis}

Hasil pengujian hipotesis dalam penelitian ini, dimaksudkan untuk melihat apakah disiplin kerja pengawasan, dan kompensasi baik secara serempak dan parsial berpengaruh signifikan terhadap kinerja pegawai Pelindo IV Cabang Pantoloan sebagai berikut:

1. Hasil uji $\mathrm{F}$ dalam rekapitulasi regresi linear berganda menujukkan nilai tingkat signifikansi sebesar 0.000 , artinya nilai tersebut lebih kecil dari taraf signifikan 0.05 . Dapat dinyatakan bahwa disiplin kerja, pengawasan, dan kompensasi secara serempak berpengaruh signifikan terhadap kinerja pegawai Pelindo IV Cabang Pantoloan.

2. Hasil uji t dalam rekapitulasi regresi linear berganda menujukkan nilai tingkat signifikansi sebesar 0.021 , artinya nilai tersebut lebih kecil dari taraf signifikan 0.05. Dapat dinyatakan bahwa disiplin kerja secara parsial berpengaruh signifikan terhadap kinerja pegawai Pelindo IV Cabang Pantoloan atau dengan kata lain hipotesis diterima.

3. Hasil uji t dalam rekapitulasi regresi linear berganda menujukkan nilai tingkat signifikansi sebesar 0.002, artinya nilai tersebut lebih kecil dari taraf signifikan 0.05 . Dapat dinyatakan bahwa pengawasan secara parsial berpengaruh signifikan terhadap kinerja pegawai Pelindo IV Cabang Pantoloan.

4. Hasil uji t dalam rekapitulasi regresi linear berganda menujukkan nilai tingkat signifikansi sebesar 0.038, artinya nilai tersebut lebih kecil dari taraf signifikan 0.05. Dapat dinyatakan kompensasi secara parsial berpengaruh signifikan terhadap kinerja pegawai Pelindo IV Cabang Pantoloan.

\section{PEMBAHASAN}


Berdasarkan hasil analisis regresi linear berganda yang telah dilakukan mengenai pengaruh disiplin kerja, pengawasan, dan kompensasi terhadap kinerja pegawai Pelindo IV Cabang Pantoloan, maka akan dilakukan pembahasan penelitian sebagai berikut:

\section{Pengaruh Disiplin KerjaTerhadap Kinerja Pegawai}

Disiplin kerja dalam penelitian ini, merupakan variabel yang berpengaruh signifikan terhadap kinerja pegawai Pelindo IV Cabang Pantoloan, walaupun tingkat disiplin kerja pegawai Pelabuhan Pantoloan Kota Palu berpengaruh signifikan tetapi masih belum optimal.Hal ini ditandai dengan adanya pegawai yang sering terlambat masuk kerja, pulang sebelum waktunya, meninggalkan kantor pada saat jam kerja Berdasarkan informasi yang ada, juga mengungkapkan bahwa masih ada pegawai yang tidak mematuh peraturan, tidak masuk kerja tanpa izin yang sah, serta sakit tanpa pemberitahuan atau surat keterangan dokter. Padahal telah ada kesempatan untuk setiap pegawai diberikan cuti oleh Pelabuhan Pantoloan selama setahun kerja.

Disiplin kerja diukur dengan beberapa dimensi yaitu disiplin waktu, disiplin moral dan disipilin administratif.Disiplin waktu merupakan suatu ketaatan terhadap segala peraturan yang telah ditetapkan dalam organisasi yang dapat meningkatkan kinerja pegawai.Dalam penelitian ini, disipilin waktu yang dimaksud adalah konsisten dalam menyelesaikan setiap pekerjaan sesuai dengan waktu yang ditentukan, tepat waktu baik datang maupun pulang sesuai dengan peraturan yang telah ditetapkan, dan selalu memproritaskan pekerjaan dari pada kepentingan pribadi.

Disiplin moral juga merupakan faktor yang memiliki peranan penting dalam meningkatkan kinerja pegawai.Penelitian disiplin moral merupakan suatu pengendalian diri saat terjadi perselisihan dalam organisasi, mengontrol emosi saat diberi teguran oleh atasan, serta akan bertindak keras pada diri sendiri ketika rekan kerja mengajak melakukan pelanggaran. Hal ini menunjukkan bahwa disiplin moral adalah tindakan yang dilakukan dari dalam diri dengan taat kepada segala peraturan yang ada, sekalipun rekan kerja mengajak untuk berbuat suatu pelanggaran tetapi selalu tetap dalam pendirian yang benar. Serta ketika atasan melalukan teguran selalu bersikap rendah hati dan dijadikan sebagai masukan positif untuk menjadi yang lebih baik. Disiplin administratif, juga merupakan faktor yang takkala penting dikarenakan disiplin ini adalah suatu sikap yang selalu menginginkan kejujuran serta keterbukaan dalam bekerja sesuai dengan kode etik pegawai, serta bertanggung jawab pada setiap konsekuensi dalam melaksanakan setiap pekerjaan yang ditugaskan, dan akan mematuhi setiap kebijakan yang telah ditetapkan oleh organisasi.

Ketiga dimensi ini dapat memberikan gambaran yang semakin jelas bahwa disiplin kerja merupakan praktek secara nyata dari para pegawai terhadap perangkat peraturan yang terdapat dalam suatu organisasi. Hal ini membuktikan disiplin kerja sebagai suatu sikap menghormati, menghargai, patuh dan taat terhadap peraturan-peraturan yang berlaku baik yang tertulis maupun yang tidak tertulis serta sanggup menjalankannya dan tidak mengelak menerima sanksi-sanksi apabila ia melanggar tugas dan wewenang yang diberikan kepadanya.Sehingga dengan adanya disiplin kerja akan sangat mendukung kelancaran seluruh kegiatan yang berada diPelindo IV Cabang Pantoloan dalam menghasilkan dan meningkatkan kinerja pegawai.

Hasil penelitian ini juga sejalan dengan penelitian yang telah dilakukan oleh Tambunan (2017), dimana hasil penelitian menunjukkan bahwa disiplin kerja berpengaruh signifikan terhadap kinerja karyawan pada PT. Coca Cola Amatil Indonesia Cabang Pekanbaru.Kemudian Wahyuni (2017) juga menyatakan bahwa variabel disiplin kerja berpengaruh signifikan terhadap kinerja karyawa PT. Teluk Luas Padang.Berbeda dengan penelitian yang telah dilakukanoleh Margaret (2017) menyatakan bahwa disiplin kerja tidak berpengaruh signifikan terhadap kinerja karyawan pada Rumah Sakit Islam At-Taqwa Gumawang Kecamatan Belitang Madang raya Kabupaten OKU Timur. 


\section{Pengaruh Pengawasan KerjaTerhadap Kinerja Pegawai}

Pengawasan dalam penelitian ini merupakan variabel yang berpengaruh signifikan terhadap kinerja pegawai Pelindo IV Cabang Palu, walaupun pengawasan berpengaruh signifikan terhadap kinerja pegawai tetapi masih belum optimal. Hal ini disebabkan pimpinan biasanya tidak berada ditempat, sehingga berdampak pada kinerja beberapa pegawai dimana target kerja yang telah ditetapkan tidak dapat tercapai secara maksimal atau sesuai dengan apa yang ditentukan oleh Pelindo IV Cabang Pantoloan.

Penelitian ini pengawasan diukur dengan beberapa dimensi, yaitupengawasan pendahuluan, pengawasan saat kerja berlangsung, dan pengawasan umpan balik.Pengawasan pendahuluan merupakan faktor yang memberikan pengaruh dalam peranan kinerja pegawai. Penelitian ini, pengawasan pendahuluan dilakukan atasan terhadap bawahan, yaitu dimana atasan melakukan pengawasan pada karyawan setiap harinya seperti melakukan melakukan pengecekan pada setiap peralatan kantor maupun melakukan pengawasan terhadap sumber daya finansial yang ada dalam organisasi. Hal ini dimaksudkan agar dalam organisasi, dapat berjalan maksimal atau sesuai dengan tujuan yang telah ditetapkan dalm program kerja

Pengawasan saat kerja berlangsung adalah dimensi yang juga berperan penting dalam meningkatkan kinerja pegawai. Hal ini, dikarenakan dengan adanya pengawasan saat jam kerja sedang berlangsung, akan dapat mengurangi tingkat kesalahan yang dilakukan oleh pegawai. Dalam hal ini adalah atasan mengawasi setiap penerapan metode yang dikerjakan oleh pegawainya, mengawasi setiap pekerjaan yang dikerjakan oleh bawahannya, maupun melakukan pengawasan terhadap penggunaan peralatan agar dapat berjalan dengan semestinya, sehingga dalam kegiatan proses kerja apabila terdapat kendala atau masalah dapat langsung teratasi dengan cepat. Pada penelitian ini, pengawasan umpan balik juga memiliki kontribusi yang dapat menghasilkan kinerja pegawai menjadi lebih baik. Dimana pengawasan umpan balik dilakukan dengan tujuan, agar kualitas setiap tugas yang telah dikerjakan oleh bawahan dapa terjaga dengan baik dengan cara selalu melakukan evaluasi hasil pekerjaan setiap harinya, serta melakukan analisis laporan keuangan setiap kegiatan yang telah dilaksanakan dalam kantor dengan tujuan untuk menghindari adanya kesalahan dalan operasional kerja.

Ketiga dimensi ini dapat memberikan gambaran yang semakin jelas bahwapengawasan memiliki peran untuk menjamin bahwa tujuan-tujuan Pelindo IV Cabang Pantoloansesuai dengan yang direncanakan. Pengawasan yang baik dimiliki oleh Pelindo IV Cabang Pantoloan terhadap pegawainya akan berakibat pada peningkatan kinerja yang baik pula, dalam hal ini adalah meningkatnya kinerja pegawai. Dengan demikian Pimpinan Pelindo IV Cabang Pantoloan diharapkan mampu untuk meningkatkan pengawasan serta menjaganya tetap optimal, pegawai dapat bekerja dengan lebih baik sesuai dengan apa yang ingin dicapai oleh Pelindo IV Cabang Pantoloan. Bagi organisasi adanya pengawasan akan menjamin terpeliharanya tata tertib dan kelancaran pelaksanaan sebuah pekerjaan yang akan berujung konsistensi peningkatan kinerja pegawai.

Hasil penelitian ini juga sejalan dengan penelitian yang telah dilakukan oleh Wahyuni (2017)dimana hasil penelitian menunjukkan bahwa pengawasan pimpinan berperngaruh signifikan terhadap kinerja karyawa PT. Teluk Luas Padang. Kemudian Tambunan (2017)juga menyatakan dalam penelitiannya pengawasan berpengaruh signifikan terhadap kinerja karyawan pada PT. Coca Cola Amatil Indonesia Cabang Pekanbaru.

Berbeda dengan penelitian yang telah dilakukan Margaret (2017)yang menyatakan bahwa variabel pengawasan tidak berpengaruh signifikan terhadap kinerja karyawan pada Rumah Sakit Islam At-Taqwa Gumawang Kecamatan Belitang Madang raya Kabupaten OKU Timur. Selanjutnya Sondole, dkk (2015) 
menyatakan bahwa pengawasan tidak berpengaruh terhadap kinerja karyawan pada PT. Pertamina (Persero) Unit Pemasaran VII Terminal BBM Bitung.

\section{Pengaruh Kompensasi Terhadap Kinerja Pegawai}

Kompensasi dalam penelitian ini, merupakan variabel yang berpengaruh signifikan terhadap kinerja pegawai Pelindo IV CabangPantoloan, walaupun kompensasi tersebut berpengaruh signifikan pada kinerja pegawai namun beberapa pegawai berpendapat masih belum sesuai dengan apa yang diharapkan, seperti pemberian insentif/bonus yang diberikan belum sesuai harapan. Dikarenakan pemberian kompensasi hanya dilakukan pada pagawai dalam rangka pencapaian target kerja atau pegawai yang memiliki kontribusi maksimal atas hasil capaian kinerja individu setiap bulan.

Penelitian dalam kompensasi diukur dengan beberapa dimensi, yaitukompensasi finansial langsung dan kompensasi finansial tidak langsung. Kompensasi finansial langsung adalah merupakan kompensasi yang dapat memberikan semangat kepada setiap pegawai dalam bekerja dan meningkatkan kinerjanya.Dikarenakan kompensasi ini, adalah pemberian gaji yang sesuai dengan posisi jabatan, maupun pemberian bonus yang dilakukan adil dengan pegawai lainnya. Selain itu kinerja pegawai akan miningkat apabila dibarengi dengan kompensasi finansial langsung, seperti pemberian tunjangan transportasi untuk mengdukung kegiatan sehari-hari setiap pegawai.

Kompensasi finansial tidak langsung juga merupakan dimensi yang memiliki peranan penting, dalam meningkatkan kinerja pegawai. Pegawai yang diberikan atau menerima kompensasi tidak langsung akan merasa dihargai dalam bekerja, sehingga akan memberikan hasil yang maksimal dalam menghasilkan kinerja. Kompensasi finansial tidak langsung diberikan kepada setiap pegawai yang sudah lama bekerja akan diberikan asuransi kesehatan maupun ketenagakerjaan. Kemudian dilakukan pembayaran biaya berobat ditanggung oleh tempat bekerja apabila belum mendapatkan kartu asuransi, serta diberikan fasilitas transportasi sebagai penunjang dalam melaksanakan kegiatan kantor.

Kedua dimensi ini dapat memberikan gambaran yang semakin jelas bahwakompensasi mengandung makna bahwa setiap kegiatan yang dilakukan oleh pegawai merupakan kegiatan profesional yang berarti terdapat imbalan atas jasa yang telah dilakukan oleh pegawai untuk organisasinya.Pemberian kompensas harus layak dan dapat diterima oleh pegawai yang telah melakukan tugasnya dengan sangat baik. Pemberian kompensasi yang sesuai, maka pegawai akan bersungguh-sungguh dan melakukan berbagai upaya agar bisa mencapai hasil kerja yang lebih baik sehingga kinerjnya bisa lebih meningkat. Kinerja yang lebih baik, tentu akan memajukan jalannya Pelindo IV Cabang Pantoloan.

Hasil penelitian ini juga sejalan dengan penelitian yang telah dilakukan oleh Tambunan (2017) dimana hasil penelitian menunjukkan bahwa kompensasi berpengaruh signifikan terhadap kinerja karyawan pada PT. Coca Cola Amatil Indonesia Cabang Pekanbaru.Kemudian Lukas, dkk. (2017) menyatakan bahwa kompensasi juga berpengaruh signifikan terhadap Kinerja Pegawai Pada Badan Keuangan Kabupaten Minahasa Utara.

\section{KESIMPULAN DAN SARAN}

\section{Kesimpulan}

Berdasarkan hasil analisis dan pembahasan yang telah dilakukan maka dapat ditarik beberapa kesimpulan mengenai pengaruh disiplin kerja, pengawasan, dan kompensasi terhadap kinerja pegawai Pelindo IV Cabang Pantoloan, yaitu:

1. Disiplin kerja, pengawasan, dan kompensasi secara serempak berpengaruh signifikan terhadap kinerja pegawai Pelindo IV Cabang Pantoloan. 
2. Disiplin kerja secara parsial berpengaruh signifikan terhadap kinerja pegawai Pelindo IV Cabang Pantoloan.

3. Pengawasan secara parsial berpengaruh signifikan terhadap kinerja pegawai Pelindo IV Cabang Pantoloan.

4. Kompensasi secara parsial berpengaruh signifikan terhadap kinerja pegawai Pelindo IV Cabang Pantoloan.

\section{Saran}

1. Hasil penelitian ini diharapkan dapat digunakan sebagai bahan masukan bagi Pelindo IV Cabang Pantoloan, agar lebih memperhatikan kompensasi khususnya tunjangan transportasi, sehingga pegawai merasa diperhatikan dan pada akhirnya akan menghasilkan kinerja yang lebih baik dan maksimal.

2. Kepada pegawai Pelindo IV Cabang Pantoloan, lebih mematuhi peraturan atau kebijakan yang telah ditetapkan seperti tepat waktu baik datang, istirahat maupun pulang kantor, sehingga dapat bekerja dengan baik dan menghasilkan kinerja yang lebih maksimal.

3. Peneliti selanjutnya diharapkan lebih mempertimbangkan dan menguji variabel lainnya yang juga mempengaruhi kinerja pegawaiPelindo IV Cabang Pantoloan misalnya, gaya kepemimpinan dan pelatihan.

\section{REFERENSI}

Byars, Rue. 2008. Human Resource Management. Mcgraw- Hill international edition. New York.

Dessler, Gary. 2011. Manajemen Sumber Daya Manusia. Edisi Bahasa Indonesia, Diterjemahkan oleh Paramita Rahayu. PT Indeks. Jakarta.

Ghozali, Imam. 2011. Aplikasi Analisis Multivariate dengan Program SPSS. Badan Penerbit Universitas Diponegoro, Semarang.

Handoko, T. Hani. 2012. Manajemen Personalia dan Sumber Daya Manusia. BPFE, Yogyakarta.

Hartono, Jogiyanto, 2013. Metodologi Penelitian Bisnis (Salah Kaprah Dan Pengalaman-Pengalaman). BPFE, Yogyakarta.

Istijanto. 2005. Riset Sumber Daya Manusia. Penerbit Gramedia Pustaka Utama, Jakarta.

Lukas Mirsa, TewalBernhard, dan WalangitanMac Donald. 2017. Pengaruh Pengawasan, Kepemimpinan Dan Kompensasi Terhadap Kinerja Pegawai Pada Badan Pengelola Keuangan Dan Barang Milik Daerah Kabupaten Minahasa Utara. Jurnal EMBAVol.5 No.2 Juni 2017, Hal.1921-1928. (https://ejournal.unsrat.ac.id/index.php/emba/article/view/16465/15959/DiaksesTanggal 07 Agustus 2018).

Margaret, Fitra. 2017. Pengaruh Pengawasan Dan Disiplin Kerja Terhadap Kinerja Karyawan Pada Rumah Sakit Islam At-Taqwa Gumawang.ISSN 2088-5644.Kolegial-Vol.3, No.1.Juni 2017. (http//:journals. stiedwisakti.ac.id/ojs/index.php//kolegial/article/download/.37/36/ Diakses Tanggal 07 Agustus 2018).

Priansa, Donni Juni. 2016. Perencanaan \& Pengembangan SDM. Cetakan Kedua. Alfabeta, Bandung.

Solimun, 2002. Multivariate Analisis Structural Equation Modeling (SEM) Usrel dan Amos, Universitas Negeri Malang, Malang.

Sondole, Erlis Milta Rin, Nelwan Olivia Syanne, dan Palandeng Indrie Debbie. 2015. Pengaruh Disiplin Kerja, Motivasi Dan Pengawasan Terhadap Kinerja Karyawan Pada PT. Pertamina (Persero) Unit Pemasaran VII, Terminal BBM Bitung. Jurnal EMBA Vol. 3 No. 3 Sept. 2015, Hal. 650-659. (https://ejournal.unsrat.ac.id/index.php/emba/article/view/9536//Diakses Tanggal 07 Agustus 2018).

[DIGUNAKAN, DI HALAMAN 8 DIKUTIP SEBAGAI SONDOLE, DKK]

Sutrisno, Edy, 2009. Manajemen Sumber Daya Manusia. Kencana Prenada Media Group, Jakarta. 
Tambunan,Julita Fransiska. 2017. Pengaruh Pengawasan, Disiplin Kerja, Dan Kompensasi Terhadap Kinerja Karyawan Pada PT. Coca Cola Amatil Indonesia Cabang Pekanbaru. JOM Fekon, Vol. 4 No. 1 (Februari) 2017.(https://media.neliti.com/media/publications/132779-ID-pengaruh-pengawasandisiplin-kerja-dan-kompensasi.pdf// Diakses Tanggal 07 Agustus 2018).

Umar, Husein. 2005. Metode Penelitian Skripsi dan Tesis Bisnis.Edisi Baru. RajaGrafindo Persada, Jakarta.

Wahyuni Rika. 2017. Pengaruh Pengawasan Pimpinan, Disiplin Kerja, Penempatan Kerja Dan Kepuasan Kerja Terhadap Kinerja Karyawan PT. Teluk Luas Padang. Majalah Ilmiah, Vol. 24, No. 1 April 2017, Hal. 129-136. (http://lppm.upiyptk.ac.id/ majalahilmiah /index.php/majalahilmiah /article/view/75/ Diakses Tanggal 07 Agustus 2018).

Winardi. 2011. Kepemimpinan dalam Manajemen. PT. Rineka Cipta. Jakarta. 